\title{
Women's community participation and management of public policies in a popular neighborhood in Rosario (Argentina)
}

\begin{abstract}
In this work we propose to analyze the trajectory of an organization formed by women from a peripheral neighborhood of Rosario's city (Argentina). From an ethnographic approach we try to account for how in the way of organizing and managing resources, there is a passage from the private to the public, leading family concerns (children stalked by drugs, violence, poverty) and domestic activities (cooking, clean, take care of children) to the community sphere. In this way, the political practices of these women, which are linked to the collective participation from a particular womanmother role, do not become exceptional biographies? We suggest that these political practices appear in the daily life, in personal relationships, among friends, neighbors, relatives and in links with state and social institutions
\end{abstract}

Volume 3 Issue 2 - 2018

\author{
Gabriela González, Silvia Alucin \\ Instituto Rosario de Ciencias de la Educación,Argentina
}

Correspondence: Gabriela González, Instituto Rosario de Ciencias de la Educación,Argentina, Tel 5434159946 86, Email glgonza2@yahoo.com.ar

Received: January 02, 2018 | Published: March 23, 2018

Keywords: women, participation, politics, domestic, community, maternity

\section{Introduction}

\section{A journey through the history of the organization}

In 2010, we arrived to Ludueña North's neighborhood from the city of Rosario (Argentina) to work with a group of women who, from that moment, gave impulse to an organization formed mainly by mothers. Our main objective was to collaborate with the emergence and development of this organization as coordinators, which is why we started from the action research approach. ${ }^{1}$ This approach facilitated us to combine this experience with academic projects of university extension and research, which in turn allowed us to perform a participant observant" ${ }^{1}, 2$ We need to clarify that this work does not take a gender perspective, although we do focus on a group of womenmothers insofar as they were the only ones in charge or interested in sustaining the organization. We consider, however, that this perspective could be a great contribution for future work, given the particularity of the organization. Ludueña's neighborhood has been a reference and anchor point of various research projects, ${ }^{3-6}$ as well as organizations and activists, mainly from the Catholic Church. According to the sector of the neighborhood through which we move, its physiognomy presents diverse contrasts, areas of irregular settlements and streets without asphalt, with absence of services. On the other hand, there are some urbanized areas, with houses of material and an incipient commercial area in the main street that crosses the neighborhood. Many of its inhabitants come from the north of Argentina, having reached the sector of the neighborhood that occupies us towards the end of the 70s. In those years, the Salesian congregation ${ }^{2}$ was also up

${ }^{1}$ Fassin's work with humanitarian organizations in which he has held management positions led him to reverse the formula of the ethnographic method and postulate an observant participation instead of a participant observation. If in the traditional scheme the ethnographic experience consisted in living in the contexts where we study, the observant participation would involve studying the contexts in which we work, changing the axis from research to action.

${ }^{2}$ The Catholic religious congregation known as Salesian or Don Bosco's through the presence of the priest Edgardo Montaldo, who remained there until his recent death. Montaldo was followed by other priests, seminarians, nuns and volunteers. In this context, the congregation built several buildings, among which stand out a school, a dining room, a vicar and six basic ecclesial communities ${ }^{3}$.

To understand the origins of this women's organization it is necessary to go back to the hyper-inflationary crisis of 1989 , in which unemployment and hunger marked the neighborhood deeply. In this context, a popular pot supported by Montaldo and neighbors of the neighborhood gave rise, at the end of the $90 \mathrm{~s}$, to the ecclesial community "Walking with Mary". In the beginning, "the food that was distributed among the neighbors was prepared in private homes and the father (priest) put the goods that Caritas ${ }^{4}$ gave him, until Raquel (neighbor) who occupied the land where the community is situated today, yielded a bit of the land where she lived so that the community was made there"(Graciela, organization's member). In 1993, Raquel, owner of the land where the community began to be raised, left the place and gave everything to the congregation. In those years, it was added to the popular pot and to the delivery of merchandise-facilitated by Caritas-various activities, religious and others aimed at raising funds for the construction of the building where the community operated. Once the building was built, they

Salesians, is an organization founded by John Bosco in Italy and then spread to other countries. Itis recognized for its work trajectories mainly around youth. 3The Base Ecclesial Communities are community spaces, as the name implies, emerged in Latin America under the inspiration of the theology of the Second Vatican Council, Medellin and Puebla. Among its objectives was evangelization and the struggle for justice, starting with the so-called "option for the poor". In its foundations they were thought of as places from which to reproduce some characteristics of the church in its beginnings, linked precisely to smaller, "fraternal" and solidary community forms.

${ }^{4}$ It is an international alliance between states financed and administered by the Catholic Church; it was installed in Argentina in the 50's, carrying out assistance and charity activities. 
began preparing food with merchandise also provided by Caritas (one serving per family member). In addition to this, new activities were incorporated: community meetings, literacy classes, basketry workshop, breastfeeding talks. With the 2001 ' $\mathrm{s}^{5}$ crisis such activities were suspended and the preparation of the aforementioned meats was replaced by the delivery of pockets with food. It was only in 2007 when a group of neighbors began to organize themselves again, so that the community could reopen its doors to the neighborhood through different workshops and training. For that moment, the landscape of that sector of the neighborhood where the community is located was also transformed. In 2005, under the "Rosario Habitat" program, an urbanization plan was carried out. It involved the paving of streets, the construction of new houses and the replacement of some access corridors by the opening of streets and the relocation of some families in the west area of the city.

In 2010, one of us who had previously worked with the Salesianscame back to the community in order to set up an organization linked to the "Mothers in Fight Movement" from Buenos Aires, whose main objective revolved around the prevention and assistance against addictions. These women joined the proposal enthusiastically, as they expressed "we wanted to do something more". Although there was no direct affiliation with the base ecclesial community, the meetings and activities of the organization took place in the church building and the links with the various priests and nuns of the congregation continued to be present in various ways. The organization was constituted as "Mothers Walking in the Fight", name that synthesizes two belongings: on the one hand to the base ecclesial community "Walking with Mary" and, on the other hand, to the reference organization "Mothers in Fight Movement". The problematic convener was the subject of addictions, given that the "Mothers in Fight Movement" worked in that sense. However, the complexity of this problem, the fears and prejudices around addictions and distrust among the women themselves, led us to run a little the focus of attention. Regarding individual experiences, only one of the mothers was able to express the situation experienced with her child (the problems caused by the addiction in terms of health, behavior, difficulty in getting help, lack of adequate assistance, resources and of appropriate policies).The other women showed interest, concern and solidarity, but the daily routine of each meeting was "my son do not consume", "it is the responsibility of the mother", as opposed to certain silences and looks that expressed a kind of fear of talking about this problem. Nevertheless, it was said in a low voice where a bunker ${ }^{7}$ was installed, who was selling drugs, whose children

${ }^{5}$ The 2001 's crisis took place in the context of marked political and economic instability that led to the resignation of President De la Rua, after the riots on December 19th and 20th. This implied a break in the long process of political, economic and social reconfiguration that had been brewing. In this sense, some authors argue that the 2001 's crisis appears as a "political event" that gives meaning to the emergence of participation spaces and social organizations with a strong territorial component. $7-9$

${ }^{6}$ The Rosario Habitat Program was created in 2001 within the framework of a series of projects co-financed by the IDB (Inter-American Development Bank) , with the objective of financing and executing "integral" projects aimed at improving the habitat of irregular settlements in the city.10

${ }^{7}$ Originally the word bunker refers to a fortification or refuge that is used for defensive purposes, but in the case here it is used to talk about places of sale of drugs, which are closed and barred-hence its link with the traditional concept of bunker-, and that have a particular structure of operation. This hierarchical structure has roughly a boss or leader and at the base of the pyramid there are soldiers, usually children in charge of the security of the place. The vocabulary were involved in drugs consume or involved in criminal networks, as well as involvement with the police.

Among them, circulated an ideal of mother-woman based on abnegation, on the fight and, especially, on the commitment to caring for children. As Sciortino ${ }^{11}$ explained, from these positions on motherhood is outlined a stereotype that reduces the plurality of links that motherhood reflects. In this way mothers are judged by what their children do, because they are considered the main responsible for their behavior and morals.

Due to the problems faced, the organization then aimed to work mainly on the path of prevention, through different activities oriented to generate alternative inclusion spaces for children and young people. On the other hand, another objective was to strengthen and provide a support space for those women who were going through different problems. Alternatives were generated which were oriented towards obtaining resources, mainly through the sale of food and the management of national projects and subsidies. In any case, beyond the focus on "prevention" and the activities carried out, a difference or tension always prevailed between who coordinated the organization and the mothers, with respect to the proposed objectives, the individual roles and the goals to be achieved (we will stop here later on). Perhaps, due to these tensions and the personal problems that each of these mothers had been going through, by the end of 2012 the organization suspended its activities until the first months of 2017 when it was reconstituted under a new slogan.

\section{Organization and political management}

During 2011, in the process of building the organization, arrived the possibility of presenting a project to the SENAF (Secretariat for Children, Adolescents and Family, dependent on the National Ministry of Social Development) in order to obtain financing for the support of the activities that were being carried out. At the same time, the request for such financing was accompanied by the possibility of being beneficiaries of several "social cases", consisting of the delivery of electrical appliances, furniture and materials for construction to "families in a situation of vulnerability". The scope of these policies allowed other families in the neighborhood to be also included, encouraging new mothers to join in some of the proposed activities, or to join the organization. This approach was neither something that occurred spontaneously, nor an emergent, product of the acquired benefit. What in any case was fostered, it was the strengthening of a network of relationships, either familiar, friendship or neighborhood that previously existed in the neighborhood and that was supported by women. In this way, on the one hand, the type of family and community organization that existed in the neighborhood and, on the other hand, certain state interventions, contributed to defining political practices based on gender. ${ }^{12}$ It is well known that many social policies reproduce the traditional sexual division of labor for its implementation. ${ }^{13,14}$ In this sense, many public policies have consolidated and promoted women as responsible for the management and support of community spaces dedicated to the feeding and care of children and young people.

The next step for the concretion of the project was to complete the forms; given its complexity this task was practically impossible for the mothers. In this way, the writing of the project, the surrender of the expenses and the deal with the officials of the Ministry in charge of accompanying and evaluating the project, was carried out 
by who coordinated the organization. However, some of the decisions regarding to the proposal and the contents of the project were worked on in workshops with the mothers. In this workshops the main problems that were perceived were shared: the difficulties that mothers faced when trying to prevent their children's contact with drugs, what happened to access to care when resources were lacking, how the neighborhood context became a determining factor, the differences between "fighting alone" and "being accompanied by other mothers" (Susana, organization's member). This clear difference between the roles of each other was part of the dynamic that characterized the organization and that became constitutive, as well as necessary. These particularities linked to the organization of the project, although here they are emphasized with the objective of problematizing the relationship between the domestic and the community sphere, are part of the more general dynamics of targeted public policies. In a synthetic way, these policies, promoted in the framework of the decentralization of the State and aimed at direct assistance, gave rise to the emergence of social programs in which self-management and participation constitute the main engine of these. ${ }^{15}$

The project was called "Building cultural experiences for family and territorial strengthening in the Ludueña's neighborhood" and involved several recreational activities for children and young people coordinated by external professionals. The activities carried out by the mothers were limited to the preparation of snacks and the purchase of merchandise, tasks that they also performed, on a smaller scale, in the daily life of their homes.

In spite of the planning carried out, different conflicts arose regarding the time distribution of the activities, the handling of the money and the responsibility for the care of the acquired goods. This caused not only fights, but also divisions that made certain activities difficult to sustain collectively.

\section{From the domestic to the community sphere}

In relation to what has been presented here, we would like to make a stopin some aspects related to the trajectory of Mothers Walking in Fight and, from there, to raise some reflections on what we have called the passage from the private or domestic to the public sphere. Segura ${ }^{16}$ states that in some experiences of spatial segregation there are two opposite but complementary processes, one that pushes towards isolation and another that leads to mobility, to precisely mitigate that isolation. In Ludueña's neighborhood, characterized by poverty, the growth of a parallel criminal economy, the confrontation between gangs and police connivance, ${ }^{6,17,18}$ fear has provoked isolation and, in turn, the need to come together to face this situation. That is to say, the context of violence implies different behaviors that push people to seclude themselves in the home and simultaneously to seek meetings in community spaces. The same happens with the experience of motherhood. On the one hand, it is established that "the women have to be in their houses and take care of the children", it is a recurring statement whenever the subject of some adolescent with problems of consumption was mentioned. On the other hand, appears the need to generate spaces for encounters with others to share the upbringing and the difficulties that arise around it.

However, the participation in the organization, although it implied this passage, was also defined by the differentiation of roles between those who coordinated and carried forward certain management functions and who launched the project in the neighborhood. In other words, it was a formal participation, according to the requirements of the project, but also an effective one, insofar as each had its predefined role even if it was implicit. This differentiation, in everyday life was in permanent tension through the constant request that some members of the organization participate in the tasks performed by the others and vice versa. From the coordination's place, we had three expectations: that the organization could grow in numerical terms, which in the future one of the mothers could take on the role of coordination and to having "political" visibility beyond the boundaries of the neighborhood. This inspired us to hold training workshops and to propose that the coordination of the meetings rotate, hoping that the mothers themselves would become references within and outside the organization. Although these attempts did not materialize, far from thinking about this outcome in terms of failure, we asked ourselves about how these women perceived and characterized the practices of those we coordinated and of themselves. Even more, in the face of the constant demand that those who coordinated also could share the tasks of preparing snacks, cleaning and taking care of children.

At that time we had different expectations, as researchers we wanted to understand the impact of public policies and stereotypes of motherhood in that particular context, from the intervention's place (as coordinators) we tried to break with these stereotypes that reduced female participation to an extension of the domestic in the public sphere. Likewise, our relationships were marked by different trajectories, while we could define ourselves as urban, university, middle class women, the biographies of them (the mothers) were marked by stories of migration, poverty, abuse, exclusion. Paradoxically, none of us was mothers back then. Probably these singularities defined, to some extent, the different views regarding participation, the role of the church in neighborhoods like Ludueña and politics. We thought that any collective project was something political, but the mothers were used to the type of community work that the Salesians developed historically in the neighborhood.

Although the practices that they carried out were not defined as a political work in native terms, but as a community work, we maintain that this implied a passage from the domestic to the public sphere, which for us presents a political dimension, as it implied a collective project. In this sense, as explained by Alejandra Massolo, the exit of women from the public sphere cannot be explained only by "the urgency of satisfying the basic needs of goods and services for the family and the improvement of living conditions in the habitat". Nevertheless, it can also be understood by "the will and aspiration of new experiences of sociability and participation in the public sphere, to acquire self-esteem and to be able to leave the domestic confinement". Somehow, what they seemed to expect it was "to build a society among women," as Michelle Rosaldo ${ }^{19}$ puts it, a kind of "refuge", as they said themselves, where they can talk about their problems, share fears, experiences, feel accompanied. These involved instances of reflection, in which what was experienced as private became visible within a collective space, making it possible that a woman's story could be interpellated by the history of another, thus opening new meanings around participation and maternity.

\section{Conclusion}

In the course of this paper, we arrive at three axes of analysis that are closely linked:

1. The role of women in organizations, 


\section{Stereotypes of women-mothers and}

3. The senses around the collective.

The first axis revolves around the dual role of women from popular sectors, in charge of demanding the State resources and the opening of community spaces; in turn, they are responsible for managing such resources and sustain these spaces. Following Russo: ${ }^{20}$ women are beneficiaries of such policies and often responsible for them. At the same time, we found that the way to take charge of the policies is crossed by a certain stereotype of the woman-mother -our second axis- that fixes them on a traditional gender identity as caretakers and cookers, while allowing them to leave the domestic border to reappropriate the public. ${ }^{20}$ Anyway, as Shore ${ }^{21}$ suggests, public policies have agency and, because of that, cannot generate contradictory and unexpected effects. That is, women can -in the way of organizing-get out of traditional gender roles. In the case we presented here, this is not what finally happened. For this reason, among others, the difference in the type of desired participation between us, who coordinated the organization and the mothers, remained as permanent tension.

This brings us to the third axis; the tension between the consolidated roles was also sustained in the different ways of conceiving the collective. The forms of participation were linked to different meanings attributed to the idea of collective. We understood that the kind of participation we made implied a political doing, while the mothers linked it to the community, in the sense granted by the church, splitting it from the political. These different points of view were articulated to the fact that the mothers conceived the political in partisan terms, as well as they related the community to their experiences of participation in the basic ecclesial communities in the neighborhood. Because of this, they could not visualize the political and social dimension of the individual problems that they had with their own children around drugs. We consider that this perspective can be linked to the stereotype of mother as the absolute responsible for her children, which feeds accusations, feelings of guilt, processes of denial that end up bypassing the structural conditioning of the drug problem.

Following Fernández Álvarez ${ }^{1}$ we believe that this should not be thought in terms of success or failure, possibility or impossibility, but that we should focus on the space built collectively, with its multiple tensions and expectations at stake. While it is true that this experience did not modify the gender stereotypes, nor allowed to generate political readings about the context of violence that characterizes the neighborhood, we believe that the construction of a community of women entailed the transformation of personal relationships, among friends, neighbors, relatives. In addition to this, these experiences allowed them to build links with state institutions and with other neighborhood organizations. Beyond the separation of the group, these transformations were in a dormant state, enabling today that community of women to be reconstituted. It will be pending to reflect on the current events of the organization and the political management and the traces that that first experience will print. ${ }^{22}$

\section{Acknowledgements}

A preliminary version of this paper was presented at the XII Reunión de Antropología del Mercosur, Posadas (Argentina), 2017. We are grateful to the organizers of the Work Group "Ethnographies about experiences of women's collective organization: political practices others", Drs. Silvana Sciortino and Mariana Gómez, Lic. Marian Nathalia Torres T. and Mgter. Rita Becker Lewkowicz, as well as to the comments of the participants.

\section{Conflict of interest}

Authors declare that there is no conflict of interest.

\section{References}

1. Fernández Á, María I. Introducción. El desafío de hacer juntos(as). In: Fernández Á, editor. Hacer juntos(as). Dinámicas, contornos y relieves de la política colectiva. Biblos, Buenos Aires: Argentina; 2016. p. 11-30.

2. Fassin D. La razón humanitaria. Una historia moral del tiempo presente. Prometeo: Buenos Aires; 2016.

3. Alucin S. Entre libros y ejemplos: principios morales en la educación secundaria, Kairos. Revista de Temas Sociales. 2013;17(31):1-17.

4. Antognini J, Germán G, Gabriela G, et al. La familia de Juancho. Cuadernos de Cátedra Metodología de Investigación y Técnicas de Estudio II. 2005;117-141.

5. Buzaglo A. Un reloj de sol en el Ludueña. Homenaje a los detenidos desaparecidos en Rosario. IV Seminario Internacional Políticas de la Memoria: Centro Cultural Haroldo Conti. Buenos Aires; 2011.

6. Hudson JP. Las partes vitales. Experiencias con jóvenes de las periferias. Tinta Limón: Buenos Aires; 2015.

7. Auyero J. La zona gris. Violencia colectiva y política partidaria en la Argentina contemporánea. Siglo XXI: Buenos Aires; 2007.

8. Merklen D. Pobres ciudadanos. Las clases populares en la era democrática (Argentina, 1983-2003). Gorla: Buenos Aires; 2005.

9. Vomaro P. 2001 antes y después: la consolidación de la territorialidad. Revista Forjando $N^{\circ} 1$. Buenos Aires; 2012. p. 106-117.

10. Passalacqua E. El área metropolitana de Rosario y la política de vivienda: problemas y desafios. Un enfoque desde la gestión: Mundo Urbano; 2005.

11. Sciortino S. Semillas, hijos y pueblos: cuando la maternidad se conforma en lucha. Revista Corpus, Archivos virtuales de la alteridad americana. 2017;7(1):97-126.

12. Lagos M. Vida cotidiana, ciudadanía y el género de la política, en Cuadernos de Antropología Social. Cuadernos de Antropología Socia. 2008;(27):91-112.

13. Masson L. La Política en femenino. Antropofagia: Buenos Aires; 2003.

14. Russo M. Escenas de la vida cotidiana: relatos y experiencias de mujeres jefas de comedores populares. Actas VIII Reunión de Antropología del Mercosur (RAM). Buenos Aires: Argentina; 2009.

15. Bonaldi P, Cecilia DC. Fragmentación y violencia en dos barrios de Moreno. In: Grimson A, Ferraudi MC, Segura R, editors. La vida política en los barrios populares de Buenos Aires. Prometeo Libros, Buenos Aires: Argentina; 2007. p. 103-128.

16. Segura R. Si vas a venir a una villa, loco, entrá de otra forma. Distancias sociales, límites espaciales y efectos de lugar en un barrio segregado del gran Buenos Aires. In: Grimson A, Ferraudi MC, Segura R, editors. La vida política en los barrios populares de Buenos Aires. Prometeo Libros, Buenos Aires: Argentina; 2009. p. 41-62.

17. CIU. Club de Investigaciones Urbanas. Rosario Arde, A Pura Adrenalina Arde: Mimeo; (2013a).

18. CIU. Ciudad boom, ciudad bang. Argentina: Revista Crisis; (2013b). 
19. Rosaldo M. Women, Culture and Society: A Theoretical Overview. In: Rosaldo MZ, Lamphere L. editors. Women, Culture and Society. Stanford: Stanford University Press; 1974. p. 17-42.

20. Russo M. La maternidad como excusa. Participación política y social de mujeres Jefas de Comedores en una villa de la Ciudad de Buenos Aires. Actas VII Jornadas de Sociología. Facultad de Ciencias Sociales, UBA, Buenos Aires: Argentina; 2007.
21. Shore C. La antropología y el estudio de la política pública: reflexiones sobre la formulación de las políticas. Revista Antípoda 10. Colombia: Facultad de Ciencias Sociales; 2010. p. 21-59.

22. Alucin S. Políticas educativas para el nivel secundario. Un análisis antropológico centrado en las perspectivas de los docentes. Revista IRICE. 2015;29:1-30 